
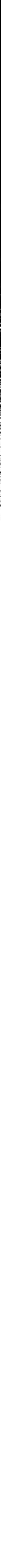


\title{
Rangeland livestock production in western Afghanistan
}

\author{
I. D. McArthur, ${ }^{*} \dagger$ Sarwar Sayad* \& Maqsood Nawim*
}

\begin{abstract}
Rangelands of Herat Province, in western Afghanistan, provide the basis for the sheep and goat industries. Data on livestock and pasture productivity; husbandry systems; and the size, major problems and attitudes to change of the various livestock-owning groups previously have not, however, been available. Research investigations and surveys were undertaken in three rangeland areas, totalling $11,800 \mathrm{~km}^{2}$, to provide this data. The areas supported a human population of over 10,000 families and 370,000 sheep and 310,000 goats in winter, and had an average stocking rate of 1.63 ha per ewe equivalent. The information available as a result of these investigations was used to prepare integrated livestock and rural development proposals.
\end{abstract}

\section{Introduction}

1. frclands provide the basis for the sheep and goat industries of Afghanistan, which werther account for 30 per cent of recorded export income and 10 per cent of recorded un Domestic Product. According to government statistics, two-thirds of the population " 19 million own some livestock, and 3 million are nomads. Herat Province, in western "Thanistan, is estimated to have a sheep and goat population of 1.5 million, but numbers - tuate considerably, depending on seasonal conditions. Sheep are predominantly of the - At-wooled, fat-tailed Gadic breed, while goats are the coarse black-haired Khalej and int. livestock owners (naldar) in the province can be classified in four categories:

ii) Comads (kochi), who spend winter in the lowland areas to the west of the Hindu Kush mountains, migrating to the highland areas in summer.

iii) Semi-nomads, who remain in the lowland areas throughout the year, moving short distances as pasture and weather conditions dictate. These people often are impoverished, owning insufficient camels to make the migration to the highland areas, and supplement their income with seasonal labouring work.

(ii) Yillagers, who may graze their animals within the village, but more usually form a communal flock and employ a shepherd (chopan) to graze the animals on rangelands near the village throughout the year.

i) Semi-sedentary villagers, who have a house, but who migrate with their animals for some period of the year, generally during summer, but in some cases during winter (where the village is subject to prolonged cold or snow). The migration may be a few kilometres, or in excess of $300 \mathrm{~km}$.

$\therefore$ four categories are not mutually exclusive; one family may have both semi-nomadic

- txperimental Kange Improvement Centre, Herat Livestock Development Corporation, P.O.

Herat, Afghanistan. The authors are grateful to the President of the Corporation for permission ivish the results of field experimental and survey work.

'Pesent address: llaryard Institute for International Development, P.O. Box 47098, Nairobi, 
and sedentary members and there is a continual interchange as fortunes fluctuate 1 it. poor members of a semi-nomadic group may find seasonal employment on agricultini lands; they may also work as chopan, assist with livestock watering or protection, or fat after lambs or camels for others.

The social structures, genealogical affinities and lifestyles of shepherding groups $w$ Afghanistan have been well studied and documented (see, for example, Ferdinand, 1968; Glatzer, 1977), but the livestock production systems have not been described in the liten ture. This paper presents the results of investigations in three rangeland areas in Hera province which were aimed at providing data relating to the livestock production system and which enabled livestock and rural development plans to be formulated.

\section{Husbandry system}

Except for an insignificant amount of intensive production, all four categories of livestock owners graze their animals on rangelands. Although villagers and semi-sedentary villagers are important contributors to the provincial flock, the majority of sheep and goats are owned by nomadic and semi-nomadic groups. The following description specifically relaten to nomadic husbandry, but the other categories operate in similar fashion.

A camping group ( $k h e l$ ) normally consists of members of the same tribe, but this is not always the case. The group is established in the winter camp by the end of October (autumn) and from that time until the end of winter, flocks water only every second or third day in order to forage as widely as possible on the low-quality pastures. Grazing land is government owned, but in practice local residents charge for the use of wells or kareze (underground water sources brought to the surface by means of excavated tunnels) and therefore have effective control of the surrounding land.

Each flock is supervised by a shepherd and assistant, and protected from wolves by one or more dogs. Shepherds are employed on an annual basis, receiving one-tenth of weaned lambs, food and some clothing and except during very severe weather when stock are brought into the tents, they remain with the flock at all times. Throughout winter, sheep are penned at night in specially constructed mud and bush shelters (gash). In late winter, ewes and young animals in poor condition receive a daily supplement of barley grain ot lucerne hay.

Lambing takes place in late February or early March, by when it is normal for the severt winter weather to be over, although spring growth of plants may not be advanced. At this time, each khel splits into smaller groups to reduce congestion at milking and each group shifts camp several times in order to maintain a high-quality feed supply.

Lambs are suckled for 2 or 3 hours after birth and then taken to the tents, where they are kept together in holes dug into the ground. Once a day, ewes are brought to the tents for milking, after which time the lambs are allowed to suckle. At 10 days, lambs are grazed as a flock, returning to the to it for suckling and at night; after 2 months they no longer return to the tent at night and at four months are weaned.

The absence of lambs while grazing allows ewes to forage widely (given that they must return to the tents each day) and ensures that greater protection from wolves and bad weather can be provided for the lambs. In average or good seasons, lamb growth seems tc be little affected by restricted suckling, and many male lambs are sold before the nexi winter, at $7-8$ months of age and $35-45 \mathrm{~kg}$ liveweight. In poor seasons, the milking proce. dure may be varied in order to provide a greater share for the lamb.

The migration into the nountains commences in April-May, and may last up to 6 weeks depending on pasture availability along the migration route and reports of conditions ir the summer areas. (The amount and duration of snowfall in the previous winter largely determine seasonal pasture production.) Shearing takes place en route, with the wool sole to travelling merchants or in Herat.

In the summer areas, khel size is reduced so that each group owns only one flock. The difficulty of controlling dense concentrations of stock near the croplands which ar 
cattered throughout the mountains sets this limit. Nevertheless, villager claims of livestock encroachment onto croplands are numerous and payments often must be made for access to watering points close to these lands. Some nomads have purchased small areas of crop frmed by tenants, in order to reduce conflict with villagers and to provide a source of prain and fodder.

On the high-quality summer pastures, growth of young stock is rapid and milk collection is at a maximum. Surplus milk is converted to butter ghee and dried yoghurt (grut), which art stored for later use by the maldar themselves; any excess finds a ready market in towns and villages. The return migration commences in August and the large khels come together again at the winter camping sites in November. When passing the city of Herat, milk products are sold and wheat (for human consumption) and barley grain (for animals) are bought.

\section{Survey areas and methods}

Three areas, centred on the Ghorian, Hamdamab and Gulran deserts of 5900, 2700 and $3200 \mathrm{~km}^{2}$ respectively, were selected as being important livestock production areas, particularly in winter (Fig. 1). The Hamdamab desert adjoins Ghorian to the north, separated

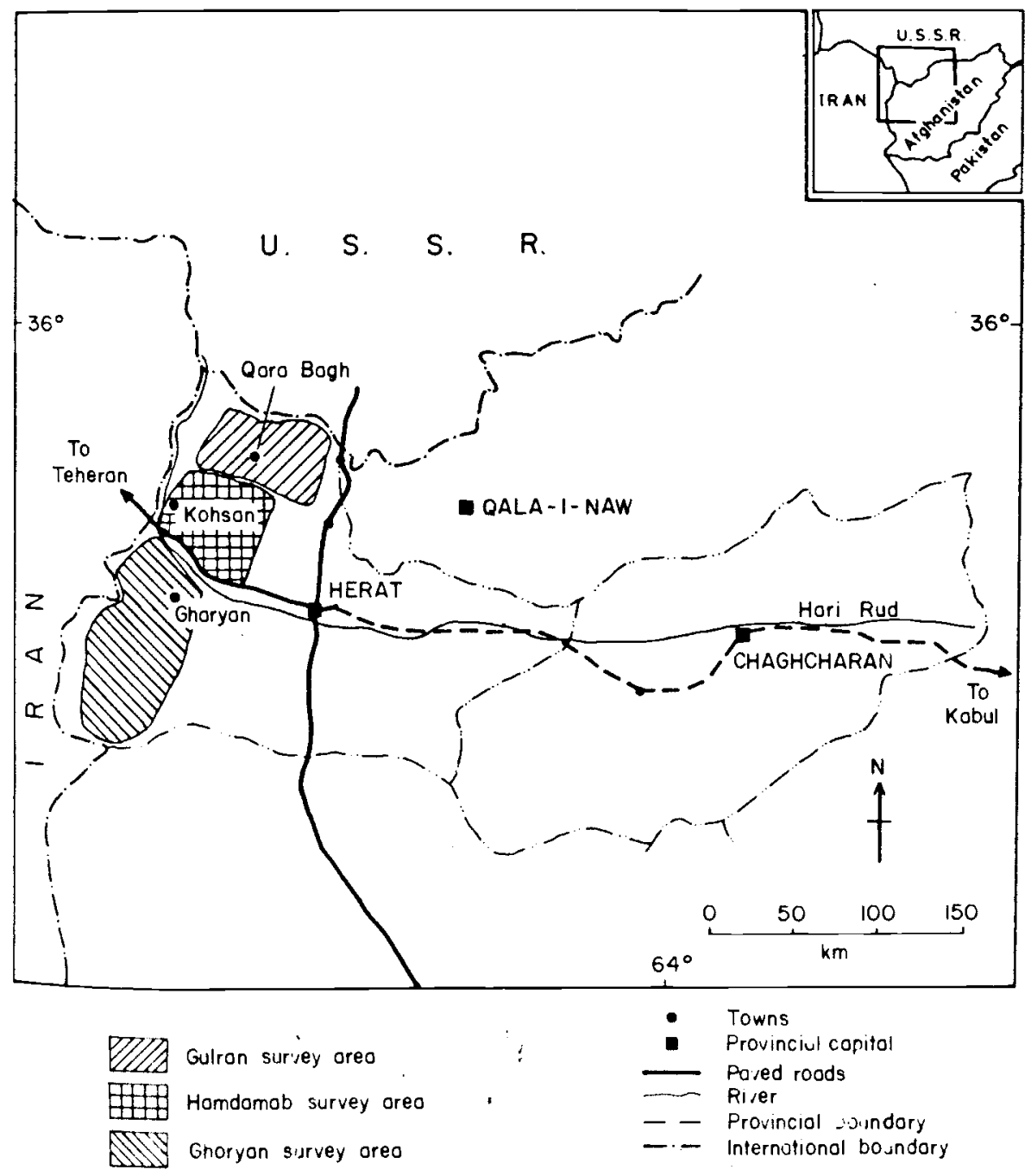

Figure 1. Map of survey areas. 
by the Hari Rud Valley and a range of low hills. Gulran is north of Hamdamab, separt by a range of hills rising to $2000 \mathrm{~m}$.

In total, the three areas represent 29.4 per cent of Herat Province. Hamdamab \& Ghorian contain few villages and interference to grazing from agricultural activitiet minimal. In contrast, parts of Gulran are densely inhabited and both irrigated and 4 land crops are more prevalent.

The owners or shepherds of all flocks grazing in the areas were interviewed-in Han. damab this was done three times (winter 1975-6, summer 1976, winter 1976-7), in Ghorian once (winter 1976-7) and in Gulran once (late winter and spring 1978). Interviews wert conducted at villages and campsites and generally involved several members of the group. A standard interview procedure was tested in other areas as a preliminary; no record were made during the interview, but data were recorded afterwards. Wherever possibte, checks on factual data were made by questioning neighbours. Data relating to human and livestock populations were collected; these allowed estimates of seasonal and annual stocking rates, year-to-year changes (in Hamdamab) and differences between the areas.

Some general information is given in Table 1 . The three areas are flat and relatively featureless, except for hills at the periphery, along which most waterpoints and villages art located and near which most nomadic, semi-nomadic and semi-sedentary groups camp. Groups which camp in the middle of the desert have long treks to water or construct smal dams. Many wells have high salt content. There are no roads but many tracks in the threa areas, and access (particularly in Gulran) is restricted by snow and mud during winte: and spring.

The dominant plant in Ghorian and Hamdamab is the low shrub Artemesia herba-alb, (trekh); Gulran supports a grassland-dominant vegetation comprising a variety of annua and perennial species. Range condition varies; in general it improves as the distance fror permanent water increases (McArthur \& Harrington, 1978). Density of useful perennit plants in Hamdamab and Ghorian varied from less than 5000 to more than 90,000 per ha seedlings were prevalent on sites in good condition and invading plants (including Alhal camelorum, Peganum harmala and Sophora pachycarpa) were common on overgrazed site Following a severe drought and very cold winters from 1970 to 1972 with a consequet drastic reduction in livestock numbers, rangelands in Herat Province were given th opportunity to recover and during the survey period, with greater than average rainfall, pastu: productivity was probably above the long-term average.

Artemesia herba-alba is extensively used for fuel in Hamdamab and Ghorian where Psoralea drupaceae is commonly used in Gulran. Cutting practices kill Artemesia herba-al but not Psoralea drupaceae (with growth buds below ground level); seedling re-establishme of Artemesia herba-alba is satisfactory in the next season provided that grazing pressu

Table 1. Description of survey areas

\begin{tabular}{|c|c|c|c|}
\hline & Ghorian & Hamdamab & Gulral \\
\hline Area $\left(\mathrm{km}^{2}\right)$ & 5900 & 2700 & 3200 \\
\hline Average rainfall $(\mathrm{mm})$ south to north & $150-220$ & $230-290$ & $300-26$ \\
\hline Soil type & \multicolumn{3}{|c|}{$\begin{array}{l}\text { Alkaline red or brown silty to sandy loams, so: } \\
\text { gravel }\end{array}$} \\
\hline Elevation $(\mathrm{m})$ & $600-1100$ & $800-1400$ & $1300-6$ \\
\hline $\begin{array}{l}\text { Average minimum temperature in coldest } \\
\text { month }(\mathrm{C})\end{array}$ & +2 & 0 & -2 \\
\hline $\begin{array}{l}\text { Average maximum temperature in hottest } \\
\text { month ("C) }\end{array}$ & +32 & +32 & +23 \\
\hline Vegetation type & Desert shrub & Desert shrub & Grassla \\
\hline Duminant species & A. herba-alba & A. herba-alba & Various \\
\hline Permancntly inhabited villages & 8 & 9 & 81 \\
\hline
\end{tabular}


not too intense (e.g. within $200 \mathrm{~m}$ of a winter camp). Family fuel requirements approach $40 \mathrm{~kg}$ per day in winter and over half this amount in summer. These are high rates (equiwent to the removal of the total dry matter from about 3 per cent of the survey areas mnually) and constitute a considerable addition to defoliation pressure.

\section{Demographic characteristics}

\section{Hamdamab}

The number of groups interviewed in three consecutive surveys is shown in Table 2. The nurveys revealed a range of forms of nomadism and sedentarism, which have been simplifird in the table. A few nomadic groups contained a small number of families owning a house in the summer area. Some semi-nomadic groups owned very few animals but shepherded villager-owned flocks; others, having lost many of their livestock in the severe drought of 1970-2, or for other reasons, moved very short distances on migration, if at all. Some of these will migrate again, even into the Hindu Kush, when the number of animals justifies it. Some of the semi-sedentary groups contained a few families without houses.

Table 2. Livestock-ozining groups in Hamdamab

\begin{tabular}{|c|c|c|c|c|c|c|}
\hline & $\begin{array}{l}\text { Groups } \\
\text { interviewed } \\
\text { winter } \\
1975-6\end{array}$ & $\begin{array}{l}\text { Groups } \\
\text { present in } \\
1975-6 \text { but } \\
\text { not present } \\
\text { in } 1976-7\end{array}$ & $\begin{array}{l}\text { Groups } \\
\text { not present } \\
\text { in } 1975-6 \\
\text { but present } \\
\text { in } 1976-7\end{array}$ & $\begin{array}{l}\text { Groups } \\
\text { interviewed } \\
\text { winter } \\
1976-7\end{array}$ & $\begin{array}{l}\text { Groups } \\
\text { interviewed } \\
\text { spring/ } \\
\text { summer } \\
1976\end{array}$ & $\begin{array}{l}\text { Total } \\
\text { groups } \\
\text { for the } \\
12 \text { months } \\
\text { spring } 1976 \\
\text { to winter } \\
1976-7\end{array}$ \\
\hline Numadic & 26 & 7 & 3 & 22 & - & 22 \\
\hline Soni-nomadic & 56 & 5 & 12 & 63 & 72 & 72 \\
\hline Stmi-sedentary & 12 & - & 6 & 18 & 37 & 55 \\
\hline \multirow[t]{2}{*}{ Villager } & 12 & - & - & 12 & 9 & 12 \\
\hline & 106 & 12 & 21 & 115 & 118 & 161 \\
\hline
\end{tabular}

There were considerable changes from one winter to the next. Seven of the 12 groups which were in the area in 1975-6 but not in 1976-7 were from one tribe, a member of which had been involved in a serious dispute with a local villager. Most of the 21 groups new to the area in 1976-7 had been camped a short distance away in the previous year and moved into Hamdamab because of improved grazing conditions. Three villages were inhabited in winter only; the owners also had houses in Gulran and moved there in summer. Five of the permanently inhabited villages had considerable irrigated cropland, whereas the other four had very little. Dryland cropping was minimal.

Nembers of some of the 37 scmi-sedentary groups which camped in Hamdamab in spring and summer owned considerable areas of cropland in the Hari Rud Valley, outside the study area. Although their flocks grazed in Hamdamab for much of the year, the owners normally only moved away from the village and into tents for the period of milking in spring and early summer. The 18 semi-sedentary groups which camped in the area in winter returned to villages in Gulran or to the east of Gulran in summer. Nine seminomadic groups used the area in summer only; most of these camped in Ghorian during vinter. A total of 161 groups used Ilamdamab at some time during the 12 months from spring 1976 to winter 1976-7. There wds an average of 17 families per group, with considerable variation between the various categories, as shown in lable 3, which relates to the 115 groups which were interviewed in winter 1976-7. Average family size was six, but this 
figure may not be accurate as human populations in each group were estimated and not subject to census.

Table 3. Human population and changes in 115 groups over one year

\begin{tabular}{|c|c|c|c|c|c|c|}
\hline & \multirow{2}{*}{$\begin{array}{l}\text { Winter } \\
1975-6 \text { : } \\
\text { No. of } \\
\text { families }\end{array}$} & \multirow{2}{*}{$\begin{array}{l}\text { No. of } \\
\text { families } \\
\text { gained } \\
\text { from } \\
1975-6 \text { to } \\
1976-7\end{array}$} & \multirow{2}{*}{$\begin{array}{l}\text { No. of } \\
\text { families } \\
\text { lost from } \\
1975-6 \text { to } \\
1976-7\end{array}$} & \multicolumn{2}{|c|}{ Winter $1976-7$} & \multirow{2}{*}{$\begin{array}{l}\text { Groups } \\
\text { with a } \\
\text { change in } \\
\text { the number } \\
\text { of familie } \\
\text { from } \\
1975-6 \text { to } \\
1976-7\end{array}$} \\
\hline & & & & Families & People & \\
\hline Nomadic & 492 & 76 & 95 & 473 & 2890 & 13 \\
\hline Semi-nomadic & 921 & 64 & 158 & 827 & 5187 & 29 \\
\hline Semi-sedentary & 262 & 31 & 23 & 270 & 1563 & 9 \\
\hline \multirow[t]{2}{*}{ Villager } & 349 & 4 & - & 353 & 1750 & 1 \\
\hline & 2024 & 175 & 276 & 1923 & 11,390 & 52 \\
\hline
\end{tabular}

There were considerable year-to-year changes especially in the composition of nomadic and semi-nomadic groups. These may have occurred for social reasons, e.g. disputes or from a desire to camp with different people. Also, an increase in livestock numbers or seasonal changes in available pasture may place a strain on feed and water resources and necessitate movement by some families. Likewise, some families are continually moving into or out of a nomadic lifestyle as fortunes or desires change.

If the 9 semi-nomadic and 37 semi-sedentary groups which were resident in summer only are added, the total number of families which lived in Hamdamab for some part of the year 1976-7, and whose income was at least partly dependant (in many cases, largely de. pendant) on grazing of livestock in Hamdamab for all or part of the year was 2407. Tribal affiliations of the 161 groups which used Hamdamab for grazing livestock at some time of the year 1976-7 are given in Table 4.

Table 4. Tribal affliations of groups in Hamdamab 1976-7

\begin{tabular}{lcccccrr}
\hline & Noor Zai & Ali Zai & Isaq Zai & Baluch & Arab & Other & Total \\
\hline Nomadic & 5 & - & 10 & - & - & 7 & 22 \\
Semi-nomadic & 13 & 22 & - & 7 & 12 & 18 & 72 \\
Semi-sedentary & 2 & 14 & - & 3 & 4 & 32 & 55 \\
Villager & 1 & 3 & - & 2 & - & 6 & 12 \\
& 21 & 39 & 10 & 12 & 16 & 63 & 161 \\
\hline
\end{tabular}

Isaq Zai was the most common tribal affiliation of nomadic groups, whereas Ali Zai was common among semi-nomadic and semi-sedentary groups, followed by Noor Zai, Arat and Baluch. There were more than 20 other tribes represented. The vernacular language in Herat Province is farsi, and most semi-nomadic, semi-sedentary and villager groups spoke this as their first language, even where the historical affiliation was with another language (pashto). Eighteen of the nomadic groups spoke pashto, retained as the first language even although the groups concerned had been resident within the farsi-speaking area for more than 100 years.

There is excessive stocking in some parts of the Hamdamab area and an allocation of grazing rights on a group or tribal basis has been suggested in an attempt to encourage 
mol husbandry of range resources. However, although there was some tendency for groups inm the same tribe to camp near to each other (especially Arab and Baluch), this was by means always the case. Because of the géographical spread of groups from the same mike and variation in language, if this allocation was done on a tribal basis it would involve major reorganization of existing grazing patterns, and could lead to difficulties of enforcement. Additionally, the annual changes within groups and the presence of groups which change their camping area very markedly from one year to the next, often in response in changed seasonal conditions, would make such allocations even more difficult.

\section{Ghorian}

(haracteristics of groups in this area are shown in Table 5. As in Hamdamab, there were considerable changes within groups from one year to the next, with a gross gain of 115 and a gross loss of 258 families from the 146 nomadic, semi-nomadic and semi-sedentary soups in 12 months. Semi-nomadic groups formed a higher proportion of the total than in Hamdamab. Many of the semi-nomadic groups claim ownership of water supplies and

Table 5. Livestock-owning groups in Ghorian, winter 1976-7

\begin{tabular}{|c|c|c|c|c|c|c|c|c|c|}
\hline & \multirow[b]{2}{*}{ Groups } & \multirow[b]{2}{*}{ Families } & \multirow[b]{2}{*}{ People } & \multicolumn{6}{|c|}{ Tribal affiliations of groups } \\
\hline & & & & $\begin{array}{c}\text { Noor } \\
\text { Zai }\end{array}$ & $\begin{array}{c}\text { Ali } \\
\text { Zai }\end{array}$ & $\begin{array}{l}\text { Isaq } \\
\text { Zai }\end{array}$ & Baluch & Other & Total \\
\hline Sumadic & 26 & 468 & 2485 & 11 & 0 & 5 & 0 & 10 & 26 \\
\hline $\begin{array}{l}\text { Semi- } \\
\text { nomadic }\end{array}$ & 106 & 1719 & 11,038 & 46 & 8 & 0 & 11 & 41 & 106 \\
\hline $\begin{array}{l}\text { Srmi- } \\
\text { sedentary }\end{array}$ & 14 & 217 & 1265 & 4 & 2 & 0 & 3 & 5 & 14 \\
\hline \multirow[t]{2}{*}{ Villager } & (8) & n.a. & n.a. & n.a. & n.a. & n.a. & n.a. & n.a. & n.a. \\
\hline & 146 & 2404 & 14,788 & 61 & 10 & 5 & 14 & 56 & 146 \\
\hline
\end{tabular}

camp near them for all or part of the year. The Ghorian desert supports a more stable population than does Hamdamab; this is reflected in tribal affiliations, with 42 per cent of groups belonging to the Noor $\mathrm{Zai}$ tribe compared to a more varied grouping in the other area. Four of the five Isaq $Z$ ai groups had been in Hamdamab for many years previous to 1976-7, but left because of the dispute mentioned above.

Semi-sedentary villagers included several groups of shepherds caring for flocks owned by residents of the large village of Ghorian, at the northern extremity of the survey area. In summer, some flocks leave the fields in this village which they graze during winter and move into the desert; this survey did not cover such flocks.

\section{Gulran}

Pasture availability was low in some parts of northern Afghanistan in winter 1977 (not (julran) and also low in some highland areas in summer 1978, so that several nomadic Rroups came to Gulran for the first time and other groups which normally migrate out of the area remained there throughout summer 1978. Characteristics of groups in this area are shown in 'I able 6.

There was a greater variety of forms of livestock ownership in Gulran than in the other wo areas. Many of the semi-nomadic groups had affiliations with villages in Gulran and there were cases of families with both semi-nomadic and villager members. A similar situation applies in other parts of Afghanistan; Glatzer (1977) instances a continual interchange in Gharjistan between a semi-nomadic and a sedentary way of life as fortunes fluctuate. 
Some of the semi-nomadic groups contained a few families with houses (used for of the year) and/or cropland; conversely, some villager groups had a few families (at ke 261) without houses and who camped in tents all year, and some families (at least 50 who had tents as well as houses and who camped near the village during spring and summer.

Table 6. Livestock-owning groups in Gulran, winter 1977-8 to summer 1978

\begin{tabular}{|c|c|c|c|c|c|c|c|c|c|c|}
\hline & \multirow[b]{3}{*}{ Groups } & \multirow[b]{3}{*}{ Total } & \multicolumn{2}{|c|}{ Families } & \multirow{3}{*}{$\begin{array}{l}\text { Groups } \\
\text { with } \\
\text { changes } \\
\text { in } \\
\text { families } \\
1977-8\end{array}$} & \multirow{2}{*}{\multicolumn{5}{|c|}{ Tribal affiliations of grouph }} \\
\hline & & & \multirow{2}{*}{$\begin{array}{l}\text { With } \\
\text { crop } \\
\text { land }\end{array}$} & \multirow{2}{*}{$\begin{array}{l}\text { With use } \\
\text { of or } \\
\text { ownership } \\
\text { of a } \\
\text { house }\end{array}$} & & & & & & \\
\hline & & & & & & $\underset{\mathrm{Zai}}{\text { Noor }}$ & $\begin{array}{r}\text { Isaq } \\
\mathrm{Zai}\end{array}$ & Mixture & Other & Toi: \\
\hline Nomadic & 32 & 371 & 5 & - & 13 & - & 29 & 1 & 2 & j) \\
\hline Semi-nomadic & 99 & 1548 & 40 & 62 & 35 & 20 & 52 & 3 & 24 & \% \\
\hline Semi-sedentary & 10 & 421 & 239 & 337 & 1 & 3 & - & 2 & $\mathbf{5}$ & 10 \\
\hline Villager & 81 & 3592 & 2017 & 3331 & 5 & 6 & 11 & 13 & 51 & 81 \\
\hline & 222 & 5932 & 2301 & 3730 & 54 & 29 & 92 & 19 & 82 & $22:$ \\
\hline
\end{tabular}

In addition, many village families hired or were allowed the use of houses as part of tenancy agreements with landlords; ownership of land and agricultural assets is very unevenly distributed. For example, one landlord owned several hectares of irrigated cropland, ovet 200 cattle and three flocks of sheep, while 29 families lived in houses owned by this man and worked almost full-time for him. This situation, and the tribal affiliations between nomadic and semi-nomadic groups and villagers, derives from the late nineteenth century, when many maldar were forcibly moved to areas of northern Afghanistan in order to secure border defences. ' $F$ ew of them had any inclination tow'ard agriculture at first . . . only the leading maldars were quick to settle and establish claims to extensive areas of farmland as well as pasturage. As large landowners, they entered the elite of rural society and gained ascendancy in that area' (Tapper, 1973).

\section{Nomadic movements}

There were annual variations in both summer and winter camping sites for some nomadic, semi-nomadic and semi-sedentary groups in all three survey areas. Groups with families collectively or individually 'owning' water facilities (and therefore the surrounding grazing land) or using them without payment, were more likely to return regularly to the same site than groups which were forced to make payments to villagers. Nomadic groups were most likely to make payments; 45 per cent of these groups made payments in the winte: area and 63 per cent made payments in the summer area, compared to less than 20 per cent of semi-nomadic and semi-sedentary groups. Only in Gulran, with a few landlords claiming ownership of extensive water resources, were payments by the latter two categories significant (approximately 30 per cent of groups made payments). In Ghorian, many of the semi-nomadic groups owning water facilities moved only very short distances during the year.

A few groups camped in two differcnt places in both winter and summer in consecutive years but 87 per cent of nomadic, semi-nomadic and semi-sedentary groups camped in the same winter arcas in two consecutive years and 92 per cent of these groups camped in the same summer areas. The only significant exception was for nomadic groups from Ghoriani, where the figures werc 46 and 53 per cent respectively and this was partly caused by thic dispute with a villager previously mentioned.

Of nonadic groups, 88 per cent camped in the Hindu Kush mountains in summer; the balance camped in Badghis (northern Afghanistan). Group size was much reduced in summer, with the 80 nomadic groups from the three survey areas in winter forming 355 
proups in summer. Even semi-nomadic group size was reduced in summer; for example, the 106 semi-nomadic groups in Ghorian in winter split into 226 groups in summer. Most ummer groups owned only one flock; this was intended to reduce animal concentration oxar croplands and so reduce the opportunities for conflict with villagers.

Villagers in the areas inhabited by nomads in summer also own livestock and wish to merve as much pasture for these as possible. Interviews in 1976 at 36 villages (800 families) within an area of $1000 \mathrm{~km}^{2}$ centred on Sahrak, an important trading centre in the mounuins near which many nomadic groups especially from Hamdamab camp in summer, mablished a livestock population of 9700 adult sheep and goats, 2000 adult cattle, 340 inrses and 490 donkeys. Approximately 30,000 adult sheep and goats owned by nomads ipent the summer in the same area and grazing disputes between villagers and nomads will arose, despite the attempts to minimize the causes of conflict.

\section{Livestock populations}

\section{Hamdamab}

The number of flocks owned by the various categories is set out in Table 7 . Average flock nizc in winter 1976-7 was 510 sheep and goats; this is similar to the situation among the Braluui of Baluchistan, to the south of Herat, where 500 animals set the upper limit which can be grazed efficiently in one unit by a man and a dog (Swidler, 1969). Also in Baluchistan, there is a lower limit of 250 , below which the shepherd (paid, as in Herat, in relation to the number of lambs reared) does not consider remuneration sufficiently attractive. This consideration also applies in Herat, where the high wages available in Iran have in the past atracted many away from what is a very difficult occupation.

Table 7. Flock ownership in Hamdamab by maldar categories

\begin{tabular}{lrcc}
\hline & Winter $1975-6$ & Summer 1976 & Winter 1976-7 \\
\hline Vumadic & 94 & - & 93 \\
Srmi-nomadic & 115 & 98 & 121 \\
Srmi-sedentary & 118 & 76 & 122 \\
Villager & 24 & 18 & 25 \\
& 351 & 192 & 361 \\
\hline
\end{tabular}

Seventy-six semi-sedentary flocks grazed the area throughout the year although the owners camped there in summer only: 15 semi-nomadic flocks grazed the area in summer mily and 38 in winter only. The total number of flocks which grazed Hamdamab during the 12 months of $1976-7$ was 376 . The number of animals of different species in summer 1976 and winter $1976-7$ is set out in Table 8 .

The differences between winter and summer represent sales, purchases, mortalities and movements into or out of Hamdamab; both winter and summer numbers include lambs horn in spring 1976. Overall, sheep exceeded goats by 70 per cent, although villagers had more goats than sheep. Females were 87 and 85 per cent respectively of total sheep and roat numbers in winter.

These findings correlate with the results of a smaller, more detailed study in winter $19 / 7-8$ during which sheep from 15 flocks were classified by age (dentition) and sex. Here, $f$ cmales were 81 per cent and 79 per cent respectively of sheep and goat numbers and lambs hrn were 95 per cent and 102 per cent of breeding female sheep and goats respectivelysome goats had kids at 1 year of age.

Rams were 1.7 per cent of breeding female sheep; this is consistent with practice throughout Afghanistan and is a reflection of the low number of rams required where flocks are shepherded and closely supervised. 
Table 8. Animal population in Hamdamab in winter 1976-7 and (summer 1976)

\begin{tabular}{|c|c|c|c|c|c|c|c|c|}
\hline \multirow{3}{*}{$\begin{array}{l}\text { Breeding } \\
\text { female } \\
\text { sheep* } \\
\text { Other } \\
\text { female } \\
\text { sheep }\end{array}$} & \multirow{2}{*}{$\begin{array}{c}\text { Nomadic } \\
20,345(0)\end{array}$} & \multicolumn{2}{|c|}{$\begin{array}{l}\text { Semi- } \\
\text { nomadic }\end{array}$} & \multicolumn{2}{|c|}{$\begin{array}{c}\text { Semi- } \\
\text { sedentary }\end{array}$} & Villager & \multicolumn{2}{|c|}{ Total } \\
\hline & & 21,440 & $14,780)$ & 19,115 & $6765)$ & $2640(2120)$ & 63,540 & $\begin{array}{l}(23) \\
\left.y^{6}\right)\end{array}$ \\
\hline & $7290(0)$ & 7917 & $(5530)$ & . 6866( & 2143) & $992 \quad(852)$ & 23,065 & $\begin{array}{l}(84) \\
16\end{array}$ \\
\hline Rams & $320(0)$ & 409 & $(306)$ & 324 & (107) & $57 \quad(38)$ & 1110 & (43i) \\
\hline $\begin{array}{l}\text { Other } \\
\text { male } \\
\text { sheep }\end{array}$ & $4287(0)$ & 4134 & $(2466)$ & 2852 & $(507)$ & $473 \quad(406)$ & 11,746 & $\begin{array}{c}(337) \\
\frac{4}{4}\end{array}$ \\
\hline $\begin{array}{c}\text { Breeding } \\
\text { female } \\
\text { goats* }\end{array}$ & $14,995(0)$ & 15,821 & $12,015)$ & 15,865 & 7015) & $4500(2900)$ & 51,181 & $\begin{array}{r}(21,930) \\
4\end{array}$ \\
\hline $\begin{array}{l}\text { Other } \\
\text { fermale } \\
\text { goats }\end{array}$ & $6480(0)$ & 7365 & $(5539)$ & 5821( & $(2460)$ & $1562(1068)$ & 21,228 & $(9067)$ \\
\hline $\begin{array}{c}\text { Breeding } \\
\text { male } \\
\text { goats }\end{array}$ & $193(0)$ & 309 & (229) & 233 & (107) & $83 \quad(55)$ & 818 & $(391)$ \\
\hline $\begin{array}{c}\text { Other } \\
\text { male } \\
\text { goats }\end{array}$ & $3855(0)$ & 4209 & $(2873)$ & 2632 & $(893)$ & $794 \quad(553)$ & 11,490 & $(4319)$ \\
\hline $\begin{array}{c}\text { Camels- } \\
\text { mature }\end{array}$ & $1277(0)$ & 997 & $665)$ & 197 & (139) & (4) & 2478 & $(808)$ \\
\hline young & $262(0)$ & 226 & (149) & 34 & (20) & (0) & 523 & (169) \\
\hline Donkeys & $518(0)$ & 650 & $(475)$ & 734 & (297) & $401 \quad(251)$ & 2303 & $(1023)$ \\
\hline Horses & $13(0)$ & 27 & $(18)$ & 21 & (11) & $5 \cdot \quad(3)$ & 66 & (32) \\
\hline
\end{tabular}

* Including those to lamb for the first time in spring 1977.

Table 9. Grazing pressure in ainter 1976-7 and (summer 1976) in Hamdamab in terms of ewe equivalents*

\begin{tabular}{|c|c|c|c|c|c|c|}
\hline & Nomadic & $\begin{array}{l}\text { Sermi- } \\
\text { nomadic }\end{array}$ & $\begin{array}{c}\text { Semi- } \\
\text { sedentary }\end{array}$ & Villager & Total & $\%$ \\
\hline Sheep & $29,595(0)$ & $\begin{array}{c}31,135 \\
(21,238)\end{array}$ & $\begin{array}{c}26,903 \\
(8896)\end{array}$ & $\begin{array}{c}3825 \\
(3126)\end{array}$ & $\begin{array}{c}91,458 \\
(33,260)\end{array}$ & $49(46)$ \\
\hline Goats & $20,192(0)$ & $\begin{array}{c}21,859 \\
(16,317)\end{array}$ & $\begin{array}{c}19,635 \\
(8409)\end{array}$ & $\begin{array}{c}5564 \\
(3658)\end{array}$ & $\begin{array}{c}67,250 \\
(28,384)\end{array}$ & $36(40)$ \\
\hline Camels & $11,539(0)$ & $\begin{array}{r}9076 \\
(6048)\end{array}$ & $\begin{array}{r}1760 \\
(1230)\end{array}$ & $\begin{array}{c}62 \\
(34)\end{array}$ & $\begin{array}{r}22,437 \\
(7312)\end{array}$ & $12(10)$ \\
\hline \multirow[t]{2}{*}{$\begin{array}{l}\text { Donkeys } \\
\text { and horses }\end{array}$} & $1349(0)$ & $\begin{array}{c}1737 \\
(1263)\end{array}$ & $\begin{array}{l}1922 \\
(789)\end{array}$ & $\begin{array}{l}1024 \\
(640)\end{array}$ & $\begin{array}{c}6032 \\
(2692)\end{array}$ & $3(4)$ \\
\hline & & & & & $\begin{array}{r}187,177 \\
(71,648)\end{array}$ & $100(100)$ \\
\hline
\end{tabular}

: Breeding female sheep 1.00 and the grazing pressure exerted by other classes of livestock related to breeding female sheep in terms of metabolic sizeother femile sheep 0.75 , rams $1 \cdot 10$, other male sheep 0.80 , breeding female goats 0.86 , other female goats 0.65 , breeding male goats 1.00 , wher male goats 0.75 , mature cancls $8 \cdot 40$, young camels $3 \cdot 10$, donkeys $2 \cdot 50$, horses $4 \cdot 15$, cattle $5 \cdot 00$. 


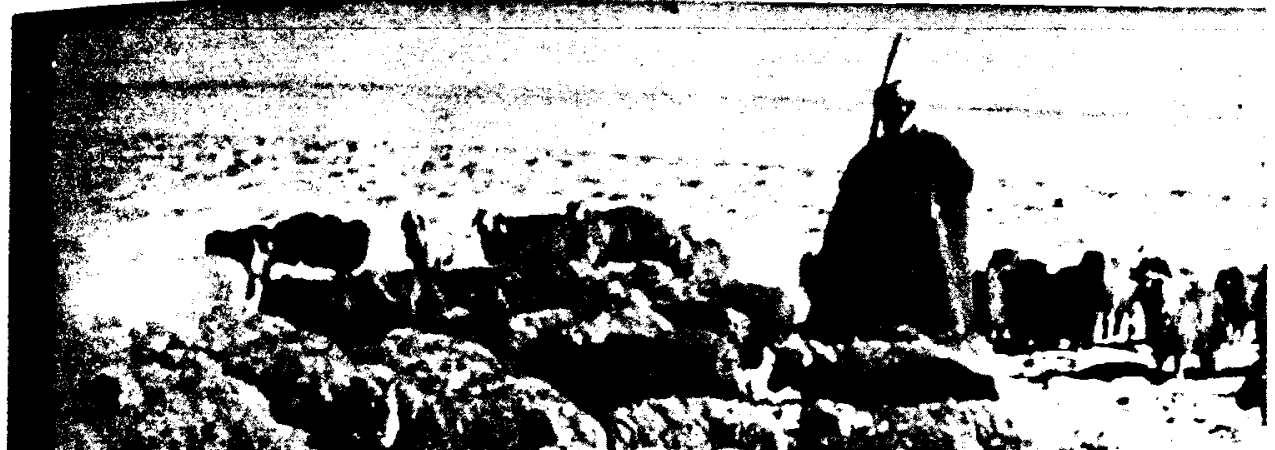

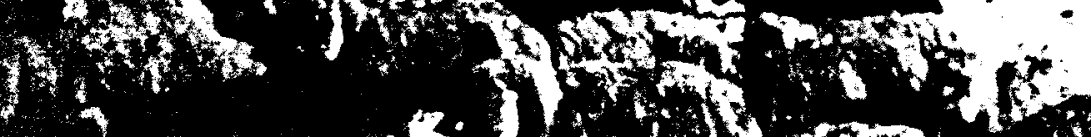
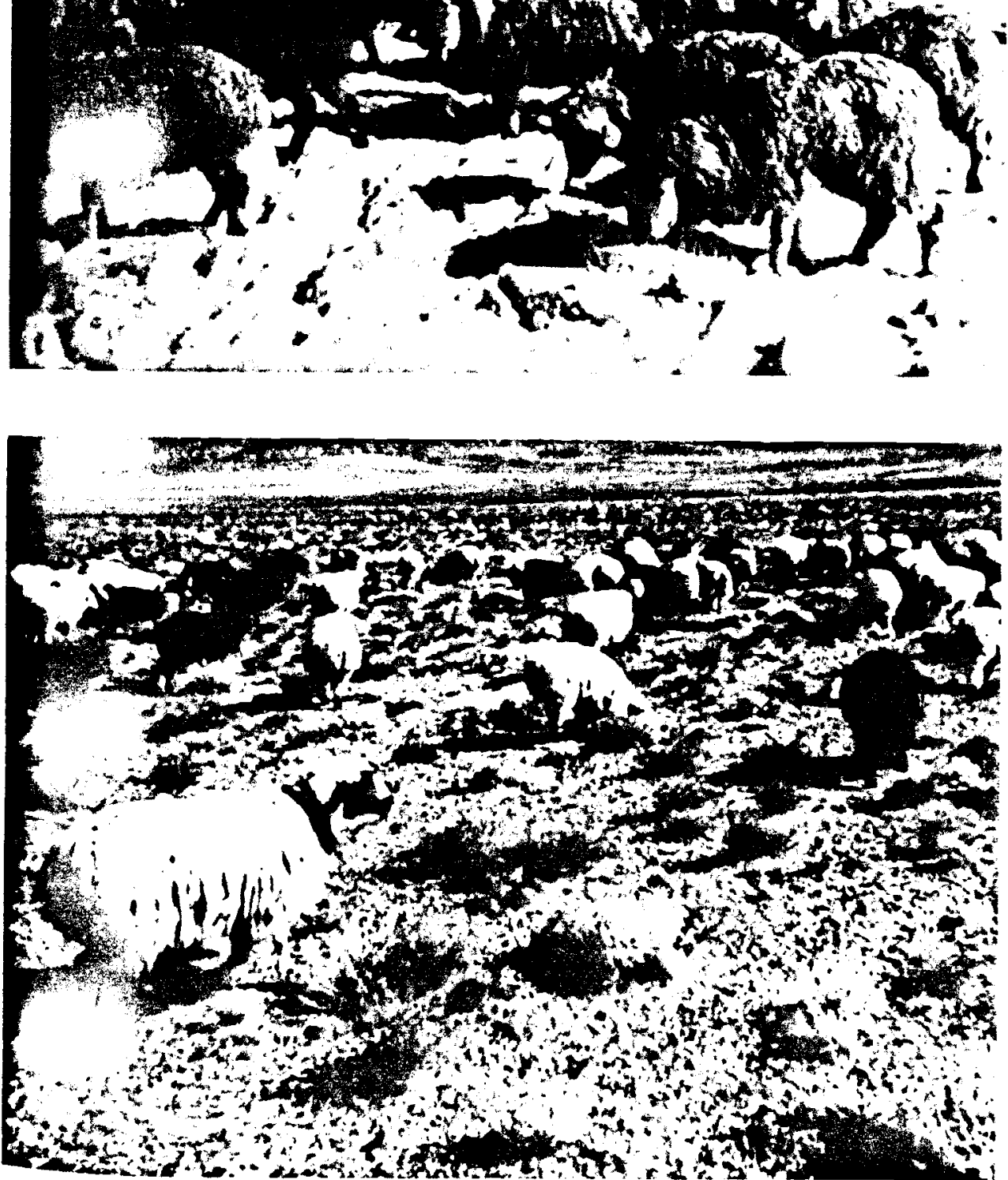

Plate 1. (a) (iadic sheep grazing on snow-covered Artemesia, Hamclanab, winter 1975-6.

(b) Cadic sheep grazing-Artemesia pasture, Handanab, spring 1977. 
In terms of ewe equivalents (Table 9) sheep were the most important species, contributing 1 ind 46 per cent of the total in summer and winter respectively. Livestock owned by mi-nomadic groups were the greatest contributors to grazing pressure in both summer and winter ( 34 and 63 per cent respectively).

livestock belonging to nomadic and semi-nomadic groups migrating out of the area memined in Hamdamab for 6.0 months on average; those belonging to semi-sedentary moups averaged 6.0 months in winter but only 4.5 months in summer, grazing near villages dong the Hari Rud Valley for the balance. Stocking rates were 1.44 and 3.77 ha per ewe nuivalent respectively in winter and summer, with an average annual rate of 2.09 .

The average number of breeding female sheep and goats per family (using winter 1976-7 finures) was a maximum for nomads ( 43.0 and 31.7 respectively) and a minimum for villagers ( 7.5 and 12.7 respectively). These figures conceal a great variability in ownership, however, and although the survey did not identify differences in ownership within groups, it did identify differences between groups (Table 10).

\section{Table 10. Variability in sheep ownership between groups, Hamdamab,} winter 1976-7

\begin{tabular}{ccccc}
\hline $\begin{array}{c}\text { Average number of } \\
\text { hircding female sheep } \\
\text { per family }\end{array}$ & Nomadic & Semi-nomadic & Semi-sedentary & Villager \\
\hline $0-10$ & 0 & 15 & 22 & 67 \\
$10-20$ & 20 & 20 & 33 & 16 \\
$20-50$ & 55 & 47 & 45 & 8 \\
$50-100$ & 15 & 17 & 0 & 4 \\
Over 100 & 10 & 1 & 0 & 5 \\
& 100 & 100 & 100 & 100 \\
\hline
\end{tabular}

\section{Ghorian}

The 146 nomadic, semi-nomadic and semi-sedentary winter groups owned 377 flocks, an increase of 12 per cent on the previous year. Some groups, however, had a reduction in flocks; as animal numbers build up, it becomes expedient to reduce the size of camping groups and the number of flocks in one place in order to lessen the pressure on grazing land and to avoid conflict with other maldar or agriculturalists. A summary of changes in flock ownership over 12 months is given in Table 11.

Table 11. Flock ownership in Ghorian by maldar category

\begin{tabular}{lcccc}
\hline & Nomadic & Semi-nomadic & Semi-sedentary & Total \\
\hline Hocks 1975-6 & 106 & 206 & 26 & 338 \\
Hocks 1976-7 & 96 & 252 & 29 & 377 \\
(iroups with increase & $6(8)$ & $42(6)$ & $4(1)$ & $52(15)$ \\
(decrease) in flocks & & & & \\
\hline
\end{tabular}

The number of animals of different species in Ghorian during winter 1976-7 and their contribution to grazing pressure is set out in 'Iable 12.

There were some semi-nomadic groups with no sheep at all but only goats; mostly this arose from poverty and not through choice. Shecp again were the most important species in terms of grazing pressure ( 47 per cent), and semi-nomadic groups the owners of the largest number of animals (62 per cent). Fiwe equivalents (excluding villager-owned sheep) vere 219,937 and, as villagers were estimated to own 33 flocks with a ewe equivalent of 
I. D. MCARTHUR, SARWAR SAYAD \& MAQSOOD NAWIM

Table 12. Animal population and grazing pressure in Ghorian, winter 1976-7

\begin{tabular}{|c|c|c|c|c|}
\hline e & Nomadic & Semi-nomadic & Semi-sedentary & Total \\
\hline \multicolumn{5}{|l|}{ Animal population } \\
\hline Breeding female sheep & 21,770 & 42,801 & 6360 & 70,93 \\
\hline Other female sheep & 8545 & 17,007 & 1910 & 27,462 \\
\hline Rams & 326 & 666 & 85 & $10 \%$ \\
\hline Other male sheep & 5330 & 7125 & 600 & 13,05 \\
\hline Breeding female goats & 21,570 & 38,956 & 3350 & $63,8 \div 6$ \\
\hline Other female goats & 6800 & 16,355 & 1165 & 24,320 \\
\hline Breeding male goats & 270 & 616 & 49 & 935 \\
\hline Other male goats & 3250 & 8549 & 362 & 12,161 \\
\hline Camels-mature & 1040 & 2398 & 136 & 3574 \\
\hline -young & 186 & 543 & 19 & 748 \\
\hline Donkeys & 434 & 679 & 164 & 1277 \\
\hline Horses & 23 & 52 & 33 & 108 \\
\hline \multicolumn{5}{|c|}{ Grazing pressure (eave equizalents) } \\
\hline Sheep & 32,802 & 61,989 & 8367 & 103.158 \\
\hline Goats & 25,678 & 51,161 & 3959 & $x^{80,798}$ \\
\hline Camels & 9313 & 21,826 & 1201 & 32,340 \\
\hline \multirow[t]{2}{*}{ Donkeys and horses } & 1180 & 1914 & 547 & 3641 \\
\hline & 68,973 & 136,890 & 14,074 & 219,937 \\
\hline
\end{tabular}

16,000 , total ewe equivalents were 235,937 and winter stocking rate was 2.50 ha per ewe equivalent.

Very few flocks come into the Ghorian desert in summer, but all semi-sedentary as well as nomadic groups leave. Summer stocking rate is estimated at 3.86 ha per ewe equivalent, with an overall annual rate of $3 \cdot 03$. The average stocking rate in Ghorian therefore is substantially less than in Hamdamab. There are variations in livestock concentration within the area, however, caused by variations in pasture conditions, productivity and concentration of watering points. Near Ghorian village, pasture depletion caused by cutting of bushes for fuel is an important factor in reducing carrying capacity.

As was the case in Hamdamab, nomadic groups had more flocks and more livestock per family than other categories, but with considerable variation between groups (Table 13).

Table 13. Variability in sheep oacnership betzcen groups, Ghorian winter $1976-7$

\begin{tabular}{cccc}
\hline $\begin{array}{c}\text { Average number of breeding } \\
\text { fomalc shecp per family }\end{array}$ & Nomadic & Scmi-nomadic & Semi-sedentar) \\
\hline $0-10$ & 0 & 28 & 15 \\
$10-20$ & 19 & 41 & 22 \\
$20-50$ & 46 & 24 & 50 \\
$50-100$ & 31 & 7 & 13 \\
Over 100 & 4 & 0 & 0 \\
& 100 & 100 & 100 \\
\hline
\end{tabular}




\section{Gulran}

The 222 groups in Gulran in winter 1977-8 owned 545 flocks, and in contrast to the other urcas, villagers owned 6763 cattle. A summary of livestock populations and ownership in given in Table 14. The 19 per cent increase in flock numbers from the previous year In a rapid build-up which could not be maintained when the (inevitable) year of low rainfall and therefore low pasture productivity occurs.

Table 14. Animal population and grazing pressure in Gulran, winter $1977-8$

\begin{tabular}{lrrrrr} 
& Nomadic & Semi-nomadic & Semi-sedentary & Villager & Total \\
\hline Amimal population & & & & & \\
Flocks 1977-8 & 87 & 249 & 8 & 201 & 545 \\
Flocks 1976-7 & 76 & 224 & 7 & 151 & 458 \\
Total sheep & 27,953 & 74,859 & 1563 & 42,059 & 146,434 \\
Total goats & 16,417 & 48,654 & 1989 & 51,406 & 118,457 \\
Camels-mature & 1028 & 2769 & 25 & 725 & 4547 \\
$\quad$-young & 190 & 385 & 10 & 151 & 736 \\
Donkeys & 506 & 1843 & 39 & 3877 & 6265 \\
Horses & 16 & 74 & 7 & 225 & 322 \\
Cattle & 4 & 30 & 487 & 6242 & 6763 \\
& & & & & \\
Cirazing pressure (ewe equivalents) & 25,158 & 67,373 & 1407 & 37,853 & 131,791 \\
Shrep & 13,134 & 38,916 & 1591 & 41,125 & 94,766 \\
Cioats & 9224 & 24,454 & 241 & 6558 & 40,477 \\
Camels & 1331 & 4899 & 189 & 10,627 & 17,046 \\
Donkeys and horses & 20 & 150 & 2435 & 31,210 & 33,815 \\
Cattle & & & & & 317,895 \\
& & & & & \\
\hline
\end{tabular}

Again, semi-nomadic groups were the owners of the largest number of animals (43 per (cnt). 'Total ewe equivalents were 317,895 with 41 per cent contributed by sheep, 30 per scnt by goats and 11 per cent by cattle. Of the cattle, 38 per cent were oxen, 18 per cent milking cows and 44 per cent calves and young animals.

IVinter stocking rate was 1.01 ha per ewe equivalent; in summer it was 0.91 ha per ewe cquivalent $(352,397$ ewe equivalents), with an annual average rate of 0.95 . These are high sncking rates, reflecting the very good seasonal growth of annual and perennial grass pustures, the number of groups which moved into Gulran for the first time and the number which remained in Gulran throughout the year (some of which had migrated to the Hindu kush or elsewhere in previous years), as well as the contribution of irrigated and dryland irops to animal (especially cattle) nutrition. In fact, Gulran was the only one of the three teas surveyed which had a higher summer than winter stocking rate, caused by the number of lambs born exceeding deaths, sales and animals leaving the area.

\section{Livestock and pasture productivity}

D)ata collection to enable productivity estimates has been under way for 3 years and is inntinuing.

Lambing and kidding percentages exceeded 90 per cent of breeding females in the 3 lears of average and above average rainfalt. Weight losses in winter approached 25 per cent of maximum summer values, but death percentages among ewes and new-born lanbs vere small, and only increase in years of sevcre cold or very low pasture availability. Deaths of ewes were 12 per cent annually; lamb deaths to weaning were 8 per cent. Lamb growth is rapid, and many males approached or exceeded $40 \mathrm{~kg}$ liveweight at 8 months 
of age $(150 \mathrm{~g}$ per day growth rate). Production of milk products varies seasonally, but averaged $1.4 \mathrm{~kg}$ of butterfat and $1.8 \mathrm{~kg}$ dried yoghurt per lactation for both sheep and goats. (Goats produce more milk per day and remain in milk for a longer period of time, but sheep's milk has a higher total solids content.) Greasy wool production was measured at $1.7 \mathrm{~kg}$ per ewe and $0.9 \mathrm{~kg}$ per lamb. Goat hair production was $0.5 \mathrm{~kg}$ per breeding female.

Very few healthy animals are slaughtered for family consumption; the age of sale of males varies with seasonal conditions and cash requirements. Sales are in Herat, in villages, to traders or, for nomadic groups, at the large fatstock market held annually at Chaghcharan in the mountains during June-July. (Interviews by the authors with over 300 groups of sellers in 1976 established that more than 75,000 nomad- and villager-owned animals go through this market each year, 86 per cent of them sheep and 93 per cent of these male animals.)

With the above production coefficients and present prices, a family owning 20 breeding sheep and 20 breeding goats would be as well off in real terms (with some income available as a reserve for bad years), as a semi-skilled labourer in Herat receiving a wage equivalent to about $\$$ U.S.40 per month. The average number of animals owned by nomads in all three areas exceeded these figures.

Quadrat cutting ( $30 \times 1 \mathrm{~m}^{2}$ quadrats) at numerous sites over 3 years enabled preliminary estimates of average productivity to be made, from which the data in Table 15 are compiled. These calculations are approximations only, as removal of dry matter by grazing and degeneration was uneven from site to site, seasonal conditions varied and will vary in the future and, ideally, many more sites should have been sampled.

Analysis by Tropical Products Institute, U.K. Ministry of Overseas Development, London, showed crude protein percentages of range pasture plants varying from 5 to 20 per cent in the middle of winter. It is not expected therefore that protein is limiting in the diet, or certainly not for much of the year, although some samples of range-collected hay from Gulran showed less than 5 per cent protein. Digestibility of Artemesia, however, may be affected by the high concentration of volatile fatty acids (Nagy, Steinhoff \& Ward, 1964) and this may affect carrying capacity at certain times of the year. Furthermore, carrying capacity varies with the type of livestock. Sheep, goats and camels select different plant species from the pasture, and this selectivity also varies in different seasons (McArthur \& Harrington, 1978). In general, sheep select forbs and grasses, while goats consume a greater proportion of foliage from woody plants, and camels, although consuming grasses and forbs, select foliage from weedy and thorny bushes where available.

Table 15. Stocking rates and estimated carrying capacities in three survey areas

Hamdamab 1977

Ghorian 1977

Gulran 1978

\begin{tabular}{|c|c|c|c|}
\hline $\begin{array}{l}\text { Annual stocking rate (ha per } \\
\text { ewe equivalent) }\end{array}$ & 2.09 & $3 \cdot 03$ & 0.95 \\
\hline $\begin{array}{l}\text { Average productivity (kg dry } \\
\text { matter of current season's } \\
\text { growth per ha) }\end{array}$ & 630 & 410 & 1040 \\
\hline $\begin{array}{l}\text { Carrying capacity* (ha per ewe } \\
\text { equivalent) }\end{array}$ & $1 \cdot 32$ & $2 \cdot 03$ & 0.80 \\
\hline
\end{tabular}

* Assuming $500 \mathrm{kgr}$ dry matter per ewe per year (National Acadenu of Sciences, 1975 ) and 60 per cent utilization.

Nevertheless, even with possible qualifications as to absolute values, it is clear that stocking rates are approaching carrying capacity and, given a run of poor seasons, nutritional stress leading to deaths can be expected.

There was a very small overlap in livestock numbers surveyed in the three areas as a fer" groups moved from one survey area to the next (e.g. from Ghorian in winter to Hamdamab 
in summer); in total, the three areas contained approximately 370,000 sheep and 310,000 goats in winter, with an average stocking rate of 1.63 ha per ewe equivalent.

\section{Major problems and attitudes to change}

In order to plan a rural development programme aimed at providing assistance in the three sreas, it is necessary to know not only details of human and livestock populations but to understand the problems and attitudes to change of the people concerned, and to incorporate their ideas in the plans. The main problems in order of importance as perceived by maldar in the three areas are set out in Table 16.

Table 16. Main problems of maldar in three survey areas

\begin{tabular}{|c|c|c|c|}
\hline & Hamdamab & Ghorian & Gulran \\
\hline Nomadic-Summer & $\begin{array}{l}\text { Payments for } \\
\text { watering }\end{array}$ & $\begin{array}{l}\text { Payments for } \\
\text { watering. Salty or } \\
\text { limited water }\end{array}$ & $\begin{array}{l}\text { Payments for } \\
\text { watering }\end{array}$ \\
\hline Winter & $\begin{array}{l}\text { Salty or limited } \\
\text { water. Cold. Lack } \\
\text { of shelter. Payments } \\
\text { for watering }\end{array}$ & $\begin{array}{l}\text { Cold. Salty or } \\
\text { limited water. Poor } \\
\text { grazing. Payments } \\
\text { for watering }\end{array}$ & $\begin{array}{l}\text { Payments for } \\
\text { watering }\end{array}$ \\
\hline \multicolumn{4}{|l|}{$\begin{array}{l}\text { Semi-nomadic and } \\
\text { Sicmi-sedentary }\end{array}$} \\
\hline -Summer & $\begin{array}{l}\text { Payments for } \\
\text { watering. Limited } \\
\text { or salty water }\end{array}$ & $\begin{array}{l}\text { Limited or salty } \\
\text { water. Payments for } \\
\text { watering }\end{array}$ & $\begin{array}{l}\text { Payments for } \\
\text { watering. Limited } \\
\text { or salty water }\end{array}$ \\
\hline -Winter & $\begin{array}{l}\text { Limited or salty } \\
\text { water. Cold }\end{array}$ & $\begin{array}{l}\text { Cold. Limited or } \\
\text { salty water. Poor } \\
\text { grazing. Human } \\
\text { food supply }\end{array}$ & $\begin{array}{l}\text { Payments for } \\
\text { watering }\end{array}$ \\
\hline \multicolumn{4}{|l|}{ Villager } \\
\hline -Summer & - & - & $\begin{array}{l}\text { Limited or salty } \\
\text { water. Disease }\end{array}$ \\
\hline -Winter & - & - & Poor grazing \\
\hline
\end{tabular}

Nomadic groups overwhelmingly nominated payment for the use of watering facilities in the summer areas as the main problem over the year. Although the amounts involved are not large, they are a continuing source of friction between villagers and nomads and, if payments are to be made, they should be to government and not to individuals. However, poor access makes the initiation of project work in the mountain grazing areas difficult at this stage of development, and it seems better to concentrate on solving problems and providing assistance in the lowland areas. Water supply is a recurrent problem for most groups in both summer and winter. This applies to quantity, quality and the need to make payments for use.

Disease is a major problem among villager flocks in Gulran. Other serious problems ate apparent but were not stated-lack of satisfactory market outlets (which may be alleviated partly by the construction of a modern slaughterhouse near Herat), overgrazing, lack of investment and employment opportunities. Much of the household and livestock work is done by women; there is marked underemployment among men, and efficiency and equity criteria require that this should not continue. With regard to technological and legislative change: 
(i) Modern veterinary treatments are well received and willingly paid for (vaccinatio at present are free but drugs must be bought).

(ii) Any restriction on the free and unfettered communal use of grazing land would b resisted. Maldar individually do not place limits on livestock numbers; the mo constraints to continued increases in flock size are droughts and cash requirement for family living expenditure, marriage and the $\mathrm{Haj}$. If available, funds surplus to these requirements are used for the purchase of breeding sheep, sheep for fattening and land.

(iii) Seventy per cent of semi-nomadic groups and 81 per cent of nomadic groups expressed an interest in owning and cultivating agricultural land which might become available through the development of underground water resources, but most would wish to continue the annual migration, while leaving some members behind to tend the crops.

\section{Summary and conclusions}

Sufficient numbers of livestock and people are indicated in the three areas to justify expen. diture on livestock improvement and rural development. Nevertheless, the surveys raise several additional questions, in particular:

(i) How do the pastoral people see their future rôle within the wider Afghan community, and to what extent are they willing or required to change traditional lifestyles and methods of production in order to progress both socially and economically? Are there large differences in attitudes within the pastoral community?

(ii) In what ways can the government assist the pastoral people to make these changes, and what social services can it provide?

(iii) How variable are livestock production parameters, especially over a run of both good and bad seasons? What is the extent of losses during droughts, how can these be avoided, and what is the rate of flock build-up during a sequence of years of above-average rainfall ?

(iv) What are the possibilities for improved livestock and rangeland pasture productivity and to what extent may such improvements lead to a more secure (or expanding) pastoril economy?

(v) Can a continually increasing human population be maintained on the rangeland areas, or are some occupational changes indicated? If so, are the necessary opportunities available, and can the new entrants be taught the required expertise ?

(vi) What is the spectrum of affluence and poverty within pastoral society? How fluid is the spectrum? What are the mechanisms for inter-family and inter-generational transfers of livestock? Can provision of social welfare facilities be channelled through the existing tribal organization?

(vii) What is the extent and magnitude of both cash and kind transactions within pastoral society and between pastoralists and others? Would more extensive incorporation within the cash economy provide an incentive for increased development efforts on the part of pastoralists themselves?

A detailed anthropological study, and a continuing research and investigation programme, are required to provide answers to these questions. As it is, the existing uncertainties, plus a conservative outlook, harsh climate and high incidence of disease (both animal and human), indicate the need for well considered and slow changes. Most maldar like their way of life, and have no desire to alter it. Nomads in particular perform a useful function in utilizing summer grazing areas that otherwise would not be exploited fully. However, there are problems associated with pastoral life, and these are likely to increase in the future as pressure on land resources develops.

Although the surveys have provided the basis for initial rural development planning in the three areas, previous false starts (e.g. in unreliable vaccine supplies) point the need for caution and careful analysis. Within any livestock-owning group, there may be both 
rery rich and very poor families. The community structure, however, is such that it may be difficult to provide assistance to the latter without simultaneously benefiting the former, will a consequent reduction in the number of poor families which can be helped within the constraints of a fixed budget.

Most importantly, a concentrated extension effort is required to encourage an attitude of more concerned use for the grazing resource leading ultimately perhaps to the allocation of discrete grazing areas to tribes or groups with the exclusion of others. Under existing mamagement practices, flock numbers build up following a run of good seasons; overr razing of pastures follows and numbers are reduced by drought and disease; pasture onditions then improve again with the reduction in numbers. If improved management and disease control methods result in reduced death losses, this could have serious implications for the long-term stability of the grazing system unless accompanied by changes in the use of grazing lands, limits to the number of animals carried and expansion of market outlets for surplus animals.

An integrated rangeland development plan for Herat Province includes these procedures, ns wil as provision of water supplies; improved access; educational facilities; human and lirsstock health care; control of cutting of Artemesia for fuel; credit availability for smallacilc water supplies and purchases of fodder for finishing and winter supplementation of shicep.

\section{References}

lirdinand, K. (1969). Nomadism in Afghanistan, with an Appendix on milk products. ViehII'irschaft und Hirten Kultur, Ethnographische Studien. Budapest: Akademiai Kiado, pp. $127-160$.

Glatzer, B. (1977). Nomaden von Gharjistan. Beiträge zur Südasienforschung, Südasien Institut linicersität Heidelberg. Wiesbaden: Franz Steiner Verlag, 22: 234pp.

McArthur, I. D. \& Harrington, G. N. (1978). A grazing ecosystem in western Afghanistan. Procedings of the 1st International Rangelands Congress, Denver, Colorado.

Nagy, J. G., Steinhoff, H. W. \& Ward, G. M. (1964). Effects of essential oils of sagebrush on deer rumen microbial function. Fournal of Wildlife Management, 28: 785-790.

National Academy of Sciences (1975). Nutrient requirements of domestic animals, Number 5. Nutrient requirements of sheep.

Swidler, W. W. (1969). Some demographic factors regulating the formation of flocks and camps among the Brahui of Baluchistan. In Irons, W. \& Dyson-Hudson, N. (Eds), International Studies in Sociology and Social Anthropology, Vol. 13, pp. 69-75. Perspectives on Nomadism. Leiden: Brill.

T'apper, N. (1973). The advent of Pashtoon Maldars in North Western Afghanistan. Bulletin of the School of Oriental and African Studies, 36 (1): 55-79. 